\title{
Front Matter: Volume 7507
}

, "Front Matter: Volume 7507," Proc. SPIE 7507, 2009 International Conference on Optical Instruments and Technology: Optical Trapping and Microscopic Imaging, 750701 (10 December 2009); doi: 10.1117/12.855338

SDIE Event: International Conference on Optical Instrumentation and Technology, SPIE. 2009, Shanghai, China 


\title{
PROCEEDINGS OF SPIE
}

2009 International Conference on Optical Instruments and Technology

Optical Trapping and
Microscopic Imaging

\author{
Xiaocong Yuan \\ Yinmei Li \\ Arthur Chiou \\ Min Gu \\ Dennis Matthews \\ Colin Sheppard \\ Editors
}

\section{9-22 October 2009 \\ Shanghai, China}

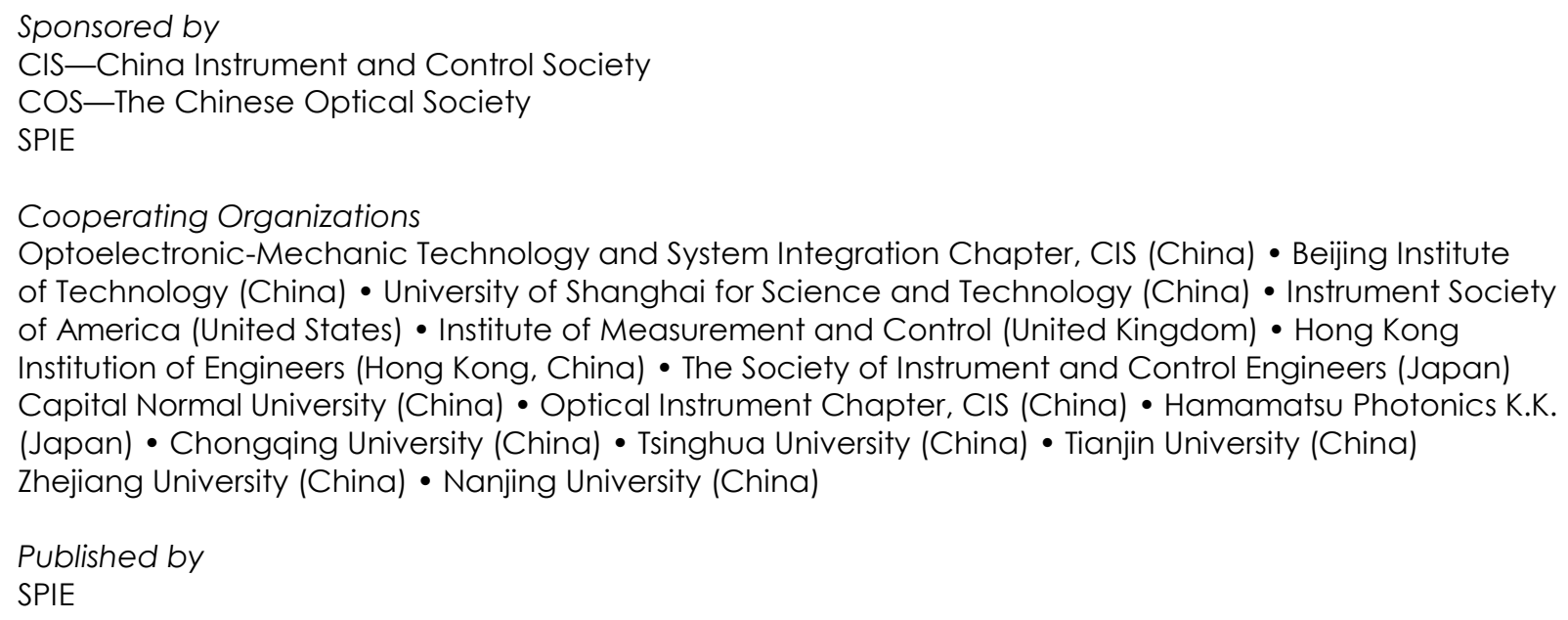

Volume 7507 
The papers included in this volume were part of the technical conference cited on the cover and title page. Papers were selected and subject to review by the editors and conference program committee. Some conference presentations may not be available for publication. The papers published in these proceedings reflect the work and thoughts of the authors and are published herein as submitted. The publisher is not responsible for the validity of the information or for any outcomes resulting from reliance thereon.

Please use the following format to cite material from this book:

Author(s), "Title of Paper," in 2009 International Conference on Optical Instruments and Technology: Optical Trapping and Microscopic Imaging, edited by Xiaocong Yuan, Yinmei Li, Arthur Chiou, Min GU, Dennis Matthews, Colin Sheppard, Proceedings of SPIE Vol. 7507 (SPIE, Bellingham, WA, 2009) Article CID Number.

ISSN 0277-786X

ISBN 9780819478931

Published by

SPIE

P.O. Box 10, Bellingham, Washington 98227-0010 USA

Telephone +1 3606763290 (Pacific Time) · Fax +1 3606471445

SPIE.org

Copyright () 2009, Society of Photo-Optical Instrumentation Engineers

Copying of material in this book for internal or personal use, or for the internal or personal use of specific clients, beyond the fair use provisions granted by the U.S. Copyright Law is authorized by SPIE subject to payment of copying fees. The Transactional Reporting Service base fee for this volume is $\$ 18.00$ per article (or portion thereof), which should be paid directly to the Copyright Clearance Center (CCC), 222 Rosewood Drive, Danvers, MA 01923. Payment may also be made electronically through CCC Online at copyright.com. Other copying for republication, resale, advertising or promotion, or any form of systematic or multiple reproduction of any material in this book is prohibited except with permission in writing from the publisher. The CCC fee code is 0277-786X/09/\$18.00.

Printed in the United States of America.

Publication of record for individual papers is online in the SPIE Digital Library.

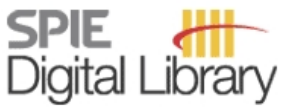

SPIEDigitalLibrary.org

Paper Numbering: Proceedings of SPIE follow an e-First publication model, with papers published first online and then in print and on CD-ROM. Papers are published as they are submitted and meet publication criteria. A unique, consistent, permanent citation identifier (CID) number is assigned to each article at the time of the first publication. Utilization of CIDs allows articles to be fully citable as soon they are published online, and connects the same identifier to all online, print, and electronic versions of the publication. SPIE uses a six-digit CID article numbering system in which:

- The first four digits correspond to the SPIE volume number.

- The last two digits indicate publication order within the volume using a Base 36 numbering system employing both numerals and letters. These two-number sets start with $00,01,02,03,04$, $05,06,07,08,09,0 A, 0 B \ldots 0 Z$, followed by 10-1Z, 20-2Z, etc.

The CID number appears on each page of the manuscript. The complete citation is used on the first page, and an abbreviated version on subsequent pages. Numbers in the index correspond to the last two digits of the six-digit CID number. 


\title{
Contents
}

\author{
vii Symposium Committees \\ ix Conference Committee \\ xi Introduction
}

\section{SESSION 1 OPTICAL TRAPPING I}

750702 Study of a colloidal sphere near flat walls using oscillating optical tweezers (Invited Paper) [7507-41]

C. Ha, Pusan National Univ. (Korea, Republic of); H. D. Ou-Yang, Lehigh Univ. (United States); H. K. Pak, Pusan National Univ. (Korea, Republic of)

750703 Effective stiffness of rotating-glass-plate time-sharing multiple optical tweezers [7507-03] Y. Ren, Univ. of Science and Technology of China (China) and Hefei National Lab. for Physical Sciences at Microscale (China); M. Chen, Univ. of Science and Technology of China (China); J. WU, Y. Li, Univ. of Science and Technology of China (China) and Hefei National Lab. for Physical Sciences at Microscale (China)

750704 Micro-Raman spectroscopy of optically trapped single cell [7507-32]

A. Ye, Y. Zhang, Peking Univ. (China)

750705 Orbital angular momentum density distribution and its simulation analysis of Gauss vortex beam [7507-15]

Y. Zhu, W. Lv, J. Zhang, M. Jing, J. Li, X. Guan, Yanshan Univ. (China)

750706 Design of a refractive optical system that converts a Gaussian beam to a ring shaped pattern beam [7507-22]

H. Ma, X. Wang, P. Zhou, X. Wang, Y. Ma, X. Xu, Z. Liu, National Univ. of Defense Technology (China)

\section{SESSION 2 OPTICAL TRAPPING II}

750707 Kinetics of DNA translocase SpolliE studied by dual optical tweezers [7507-10]

L. Ling, Institute of Physics (China); E Qu, Institute of Physics (China) and Yunnan Academy of Scientific \& Technical Information (China); H. Guo, C. XU, Z. Li, L. Huang, D. Zhang, Z. Li, Institute of Physics (China)

750708 Debye series analysis of radiation pressure force exerted on a spherical particle [7507-11] R. Li, X. Han, Xidian Univ. (China); K. F. Ren, UMR 6614/CORIA, CNRS, Univ. and INSA de Rouen (France)

750709 Radiation forces of anomalous hollow beams on a Rayleigh particle [7507-18] Y.-N. Liu, X. Lu, C.-L. Zhao, Zhejiang Univ. (China) 
7507 OA Twist phase induced changes of radiation force of a Gaussian Schell-model beam on a Rayleigh dielectric sphere [7507-28]

C. Zhao, Y. Cai, Soochow Univ. (China); X. Lu, Zhejiang Univ. (China)

\section{SESSION $3 \quad$ MICROSCOPIC IMAGING}

7507 OB Optical coherence tomography for ultrahigh-resolution 3D imaging of cell development and real-time guiding for photodynamic therapy (Invited Paper) [7507-01]

T. Wang, J. Zhen, B. Wang, P. Xue, Tsinghua Univ. (China)

7507 OC Development of a high speed spectral domain optical coherence tomography system at 835 nm (Invited Paper) [7507-35]

K. Wang, Z. Ding, J. Meng, M. Chen, T. Wu, Zhejiang Univ. (China)

7507 OE Study on the LTE and its effect on the measurement accuracy in calibration-free laser-induced breakdown spectroscopy [7507-09]

Q. Chen, W. Zhou, K. Li, J. Long, Zhejiang Normal Univ. (China)

7507 OF PDT-treated apoptotic cells induce macrophage synthesis NO [7507-24]

S. Song, D. Xing, F. F. Zhou, South China Normal Univ. (China); W. R. Chen, South China Normal Univ. (China) and Univ. of Central Oklahoma (United States)

7507 OG Thick film geometric parameters measurement by white light interferometry [7507-06] L. Ma, T. Guo, F. Yuan, J. Zhao, X. Fu, X. Hu, Tianjin Univ. (China)

$7507 \mathrm{OH} \quad$ Multifocus CARS microscopy for realtime vibrational imaging [7507-21] M. Hashimoto, T. Minamikawa, H. Niioka, T. Araki, Osaka Univ. (Japan)

7507 Ol Lysosomal photodamage induces cell death via mitochondrial apoptotic pathway [7507-25]

L. Liu, X. Wang, H. Li, South China Normal Univ. (China)

POSTER SESSION

7507 0J Determination of the axial stiffness of an optical trap with information entropy signals [7507-02]

M. Zhong, J. Zhou, J. Wu, Univ. of Science and Technology of China (China); Y. Li, Univ. of Science and Technology of China (China) and Hefei National Lab. for Physical Sciences at Microscale (China)

7507 OK A novel fiber optical tweezers with FZP structures on fiber end-face [7507-14]

F. Hao, R. Wang, J. Wang, Tsinghua Univ. (China)

$7507 \mathrm{OL} \quad$ Application of cytoplasmic $\mathrm{Ca}^{2+}$ fluorescence imaging techniques to study the molecular mechanisms of exercise-induced fatigue eliminated by Chinese medicine ginseng extract [7507-30]

Y. Liu, Y. Zhao, H. Zhang, S. Liu, South China Normal Univ. (China)

7507 OM Optical microscopic imaging based on VRML language [7507-36]

X. Zhang, Z. Zhang, J. Sun, Univ. of Shanghai for Science and Technology (China) 
7507 ON Improving the framing capability in high-speed photography by Fraunhofer digital holography [7507-46]

X. Lu, J. Li, H. Chen, S. Xu, Shenzhen Univ. (China)

Author Index 
Downloaded From: https://www.spiedigitallibrary.org/conference-proceedings-of-spie on 26 Apr 2023

Terms of Use: https://www.spiedigitallibrary.org/terms-of-use 


\title{
Symposium Committees
}

\author{
General Chair
}

Songlin Zhuang, University of Shanghai for Science and Technology (China)

General Cochairs

Yuri Chugui, New Siberia Academy of Sciences (Russian Federation)

Arthur E. T. Chiou, National Yan-Ming University (Taiwan, China)

Honorary Chairs

Daheng Wang, Chinese Academy of Sciences (China)

Teruo Hiruma, Hamamatsu Photonics K.K. (Japan)

Guoguang Mu, Nankai University (China)

Bingkun Zhou, Tsinghua University (China)

Technical Program Chair

Guofan Jin, Tsinghua University (China)

Technical Program Cochairs

Yimo Zhang, Tianjin University (China)

Sien Chi, National Chiao Tung University (Taiwan, China)

Local Organizing Committee Chair

Youhua Wu, China Instrument and Control Society (China)

Local Organizing Committee Cochairs

Guoqiang Ni, Beijing Institute of Technology (China)

Daoyin Yu, Tianjin University (China)

Yulin Xi, Beijing Hamamatsu Photon Techniques Inc. (China)

Zhengji Ni, Shanghai University of Science and Technology (China)

Jinxue Wang, SPIE (United States)

General Secretary

Youhua Wu, China Instrument and Control Society (China) 
Administrative Vice General Secretary

Boyu Ding, Beijing Institute of Technology (China)

Vice General Secretaries

Hanquan Zhang, China Instrument and Control Society (China)

Yuejin Zhao, Beijing Institute of Technology (China)

Xiongwen Qin, China Instrument and Control Society (China)

Tiegen Liu, Tianjin University (China)

Qionghui Feng, Shanghai University of Science and Technology (China)

Cunlin Zhang, Capital Normal University (China)

Local Organizing Committee

Weimin Chen, Chongqing University (China)

Hongda Chen, Institute of Semiconductors, CAS (China)

Yan Zhang, Capital Normal University (China)

Shangzhong Jin, Chinese Jiliang University (China)

Boshun Hu, Modern Scientific Instruments (China)

Libo Yuan, Harbin Engineering University (China)

Tian Lan, Beijing Institute of Technology (China) 


\title{
Conference Committee
}

\author{
Conference Chairs
}

Xiaocong Yuan, Nankai University (China)

Yinmei Li, University of Science and Technology of China (China)

Arthur Chiou, National Yang-Ming University (Taiwan, China)

Min Gu, Swinburne University of Technology (Australia)

Dennis Matthews, University of California, Davis (United States)

Colin Sheppard, National University of Singapore (Singapore)

Program Committee

Zhongping Chen, University of California, Irvine (United States)

Daniel Elson, Imperial College London (United Kingdom)

Paul French, Imperial College London (United Kingdom)

Bruce Z. Gao, Clemson University (United States)

Jesper Glückstad, Danmarks Tekniske Universiteit (Denmark)

Aaron H.P. Ho, The Chinese University of Hong Kong (Hong Kong China)

Hui Ma, Tsinghua University (China)

Chinlon Lin, Nanyang Technological University (Singapore)

Xuanhui Lu, Zhejiang University (China)

H. Daniel Ou-Yang, Lehigh University (United States)

Monika Ritsch-Marte, Innsburck Medical University (Austria)

Halina Rubinsztein-Dunlop, The University of Queensland (Australia)

Da Xing, South China Normal University (China)

Xiaohui Zhang, Chinese Academy of Sciences (China)

Siwei Zhu, Tianjin Union Medicine Centre (China) 
Downloaded From: https://www.spiedigitallibrary.org/conference-proceedings-of-spie on 26 Apr 2023

Terms of Use: https://www.spiedigitallibrary.org/terms-of-use 


\section{Introduction}

These proceedings result from the 2009 International Conference on Optical Instrument and Technology (OIT'09), held in Shanghai, China, 19-21 October 2009. The conference was the second event following the success of OlT'08 and it was sponsored and supported by SPIE, China Instrument and Control Society (CIS), and the Chinese Optical Society (COS).

OIT'09 was a professional conference which was combined with the exhibition of The 20th Fair for Measurement Instrumentation and Automation (MICONEX).

OIT'09 focused on instrument science and related technology involved in many technical aspects such as detection; observation; information collection, transfer and storage; communication; economization on energy; environmental protection; inspection and prevention of food security, traffic safety and mine safety; measure and control for aviation and space engineering, etc.

These proceedings, a collection of eight volumes, contain the accepted oral and poster papers presented at OIT'09. It is truly a great pleasure for me that the most recent progress in optical instrumentation technology is reported in the OIT'09 proceedings. I firmly believe that the papers included in these volumes will provide reference information in up-to-date techniques of optical instrumentation technology.

The OlT'09 conference collected over 630 papers from different countries or regions of the world. Over 400 authors came from more than 14 countries, including Canada, Iran, Japan, Russia, Singapore, USA, Sweden, Switzerland, Pakistan, the Netherlands, Republic of Korea, Slovenia, Germany and China. Published in these eight volumes of the Proceedings of SPIE are close to 455 papers. The technical fields of the presented papers at the conference cover a lot of current advanced technologies. The cutting-edge technologies and applications of optical instruments are discussed. Quite a few invited papers describe exciting achievements in the fields of optical instrument technology. It is evident that the OIT'09 conference has provided an excellent platform for participants and colleagues in research and development to share the technical progress and to develop new partnerships or broaden new markets.

SPIE has given great support to organize this international conference by collaborating with us in the whole organizing process from paper collection to the proceedings publication. COS has provided enough support and assistance.

Finally, on behalf of CIS and conference general chairs, I would like to heartily thank our supporters and committee members for all they have done for this conference. Thanks also go to all authors for their contributions; to all of the 
participants and friends for their interest, especially those who have traveled great distances and taken time from their busy schedules to attend the conference. Thanks also go to the staff of COS for their support. I am also grateful to the SPIE staff for their support and collaboration in publishing these eight volumes.

Songlin Zhuang Chairman, China Instrument and Control Society (CIS) 